\title{
HUBUNGAN LAMA BEKERJA PERAWAT DENGAN TEKANAN IRIGASI LUKA SAAT PERAWATAN LUKA DI BANGSAL BEDAH
}

\section{RELATION BETWEEN LENGTH OF WORK WITH IRRIGATION PRESSURE OF WOUND CARE IN SURGERY WARD}

\author{
Suyanto \\ Program Studi Pendidikan Keperawatan, Fakultas Ilmu Keperawatan, \\ Universitas Islam Sultan Agung Semarang
}

\begin{abstract}
ABSTRAK
Perawatan luka merupakan tindakan mandiri perawat yang mencakup rangkaian tindakan - tindakan yang simultan. Dimulai dari membuka balutan, membersihkan, dan menutup luka. Tindakan membersihkan luka bisa dilakukan dengan menggunakan tehnik irigasi. Tehnik ini sangat tergantung dari konsistensi tekanan irigasi yang dilakukan. Salah satu hal yang dapat mempengaruhi konsistensi tekanan irigasi adalah lama bekerja perawat di bangsal bedah. Penelitian ini ingin melihat sejauh mana hubungan antara lama bekerja dengan tekanan irigasi luka. Desain cross sectional digunakan dalam penelitian ini, stratified random sampling dengan jumlah sampel 92 responden. Rank spearman test digunakan sebagai uji analisis dengan hasil $\mathrm{p}$ value $<0,05, \mathrm{r}=-0,21$ ada hubungan antara lama bekerja dengan tekanan irigasi luka. Diharapkan penelitian lainnya mengenai hubungan lingkar lengan perawat dengan tekanan irigasi luka.
\end{abstract}

Kata kunci : Lama bekerja; irigasi luka; perawatan luka

\begin{abstract}
The wound care which is the nurse's independent action includes a series of simultaneous actions. It starts from opening bandages, cleaning, and closing. Actions to clean the wound can be done by using irrigation techniques. This technique depends on the consistency of irrigation pressure. One of the things that can affect the consistency of irrigation pressure is the long working nurse in the surgical ward. Aim of this study is to see the relationship between length of work with the pressure of wound irrigation. Cross sectional design was used in this study with stratified random sampling technique with a sample size of 92 respondents. Rank spearman test is used as analytical test with result $\mathrm{p}$ value $<0,05, \mathrm{r}=-0,21$. there is a correlation between length of work with wound irrigation pressure. Another research is expected on the circumference of arms with pressure of wound irrigation.
\end{abstract}

Keywords : length of work, wound irrigation, wound care 


\section{PENDAHULUAN}

Ulkus diabetikum merupakan salah satu komplikasi yang sering terjadi pada pasien diabetes melitus. Kejadian ulkus diabetikum semakin meningkat, hal ini didasarkan dari data di Amerika serikat yang menyatakan bahwa total kejadian ulkus diabetikum sebanyak 1350 kasus $^{6}$. Sedangkan secara umum, kejadian luka akibat cidera kecelakaan sebanyak 24,7\% dan luka karena penyebab lainnya seperti terkena benda tumpul atau tajam sebanyak $16,7 \% 5$. Semakin meningkatnya insidensi luka baik yang disebabkan karena faktor eksternal maupun karena gangguan metabolik diperlukan penanganan yang tepat sehingga mempercepat penyembuhan luka

Tehnik perawatan luka terdiri dari 4 tindakan yang simultan dilakukan, yaitu membuka balutan, membersihkan luka, mengobati luka dan menutup luka. Pada tahapan pembersihan luka, ada 2 (dua) tehnik yang bisa dilakukan, dimulai dari usap dan irigasi ${ }^{8}$. Hal ini sesuai dengan hasil penelitian yang relevan menyatakan bahwa penggantian balutan, pembersihan luka, fiksasi balutan merupakan tindakantindakan yang dapat dilakukan untuk memberikan rasa nyaman pada pasien yang mengalami luka ${ }^{4}$.

Irigasi luka yang merupakan salah satu tehnik pembersihan luka dilakukan dengan mengacu pada konsistensi tekanan yang dikeluarkan oleh plabot saat merawat luka. Irigasi luka dapat digunakan untuk menghilangkan benda asing, eksudat pada luka dengan menggunakan cairan isotonik atau $\mathrm{NaCl}$ 0,9\%. Penelitian yang terkait lainnya menyatakan bahwa tekanan irigasi yang optimal akan mengurangi jumlah bakteri ${ }^{14}$.

Berdasarkan penelitian terkait bahwa tekanan yang optimal untuk dilakukan irigasi luka adalah 10-15 $\mathrm{psi}^{3}$. Apabila tekanan yang diberikan kurang dari 10 psi maka eksudat, benda asing yang menempel pada luka akan sulit untuk dihilangkan, akan tetapi jika tekanan irigasi yang diberikan melebihi 15 psi maka ada kemungkinan eksudat, benda asing dan bakteri akan semakin masuk kedalam jaringan kulit.

Banyak faktor yang dapat mempengaruhi irigasi luka. Faktor-faktor tersebut antra lain jenis kelamin, lama bekerja, kekuatan genggaman, alat monitor irigasi luka. Beberapa kendala yang dialami perawat saat melakukan irigasi luka adalah perawat belum mengetahui berapa tekanan yang diberikan saat irigasi serta konsistensi tekanan dari awal melakukan irigasi sampai selesai irigasi. Kendala lain adalah bervariasinya lama bekerja perawat. 
Berdasarkan hasil studi pendahuluan di bangsal bedah, perawat menyatakan bervariasinya lama bekerja perawat di bangsal bedah menyebabkan saat irigasi juga tidak bisa optimal. Selain itu adalah saat melakukan irigasi luka, perawat hanya memberikan tekanan pada flabot tanpa perawat tahu besaran tekanan irigasinya. Mengacu pada hal tersebut, maka peneliti menetapkan tujuan penelitian yaitu sejauh mana hubungan antara lama bekerja dengan tekanan irigasi saat perawatan luka di rumah sakit wilayah Kota Semarang.

\section{METODE}

Instrumen yang digunakan dalam penelitian ini adalah kuesioner dan alat artriphi. Kuesioner dimaksudkan unruk mendapatkan data lama bekerja, sedangkan artriphi digunakan untuk mengetahui tekanan irigasi. Penelitian ini merupakan penelitian observasional dengan cross sectional design. Pengambilan data di lakukan di bangsal bedah rumah sakit wilayah Kota Semarang sebanyak 92 perawat. Adapun tehnik samplng yang digunakan adalah stratified random sampling.

\section{HASIL}

Tabel 1 Distribusi rata-rata lama bekerja dan tekanan irigasi luka

\begin{tabular}{|c|c|c|c|c|c|}
\hline Variabel & $\begin{array}{l}\text { Mean } \\
\pm \text { SD }\end{array}$ & $\begin{array}{c}\text { Medi } \\
\text { an }\end{array}$ & $\begin{array}{l}\text { Min- } \\
\text { Max }\end{array}$ & $\begin{array}{c}95 \% \\
\text { CI }\end{array}$ & $\mathbf{n}$ \\
\hline $\begin{array}{c}\text { Lama } \\
\text { bekerja }\end{array}$ & $\begin{array}{c}4,72 \pm \\
2,66\end{array}$ & 4,00 & $1-10$ & $\begin{array}{c}3,72- \\
4,82\end{array}$ & $\begin{array}{l}9 \\
2\end{array}$ \\
\hline $\begin{array}{c}\text { Tekanan } \\
\text { irigasi } \\
\text { luka }\end{array}$ & $\begin{array}{l}5,65 \pm \\
1,889\end{array}$ & 5,00 & $2-10$ & $\begin{array}{c}5,26- \\
6,04\end{array}$ & $\begin{array}{l}9 \\
2\end{array}$ \\
\hline
\end{tabular}

Tabel 1 diatas dapat dilihat bahwa rata-rata lama bekerja perawat di bangsal bedah yakni 4,7 tahun dengan perawat paling lama bekerja yakni 10 tahun dan paling sedikit 1 tahun. Sedangkan rata-rata tekanan irigasi luka yaitu 5,6 psi dengan tekanan paling rendah 2 psi dan paling tinggi 10 psi.

Tabel 2. Analisis hubungan lama bekerja dan tekanan irigasi luka

\begin{tabular}{lccc}
\hline Variabel & \multicolumn{2}{c}{$\begin{array}{c}\text { Tekanan irigasi } \\
\text { luka }\end{array}$} & n \\
\cline { 2 - 3 } & $\mathbf{r}$ & $\boldsymbol{p}$ value & \\
\hline $\begin{array}{l}\text { Lama } \\
\text { bekerja }\end{array}$ & $-0,219$ & 0,036 & 92 \\
\hline
\end{tabular}

Tabel 2 menunjukkan bahwa hasil uji analisis rank spearman didapatkan ada hubungan antara lama bekerja dengan tekanan irigasi luka ( $p$ value $<0,05$ ). adapun hubungan keeratan lemah ditunjukkan dengan nilai $r=-0,219$, hal ini menunjukkan bahwa semakin lama perawat bekerja maka semakin kecil tekanan irigasi saat melakukan perawatan luka. 


\section{PEMBAHASAN}

Lama bekerja berhubungan erat dengan peningkatan ketrampilan perawat. Penelitian yang relevan menyatakan bahwa ada hubungan antara lama bekerja dengan kinerja perawat $(p \text { value }<0,05)^{7}$. Hal ini dapat dilihat dari tabel 1 bahwa rata-rata perawat yang bekerja dibangsal bedah adalah 4,7 tahun. lama bekerja seseorang akan menunujukkan semakin lama seseorang bekerja maka semakin terampil dan berpengalaman dalam melaksanakan pekerjaan, khususnya dalam perawatan luka yang berkaitan dengan tekanan irigasi luka.

Tekanan irigasi luka merupakan jumlah tekanan yang digunakan dalam irigasi luka. Irigasi luka menjadi faktor penentu dalam keberhasilan pembersihan luka. Tekanan irigasi dalam membersihkan luka ada 2 yaitu tekanan tinggi (35-70 psi) dan tekanan rendah (1-15 psi $)^{2}$. Hasil pada tabel 1 didapatkan data bahwa rata-rata tekanan irigasi luka sebesar 5,6 dengan tekanan terendah adalah 2 dan tekanan tertinggi adalah 10. Asumsi peneliti bahwa rata-rata tekanan irigasi masih rendah sehingga dimungkinkan dampak yang ditimbulkan dari irigasi tersebut tidak akan maksimal. Sehingga dimungkinkan masih adanya eksudat, benda asing ataupun bakteri yang menempel pada luka tersebut.

Nilai tekanan irigasi yang dilakukan perawat dipengaruhi oleh umur, jenis kelamin dan lama kerja seseorang. Nilai Kekuatan otot pada laki-laki mencapai puncak pada umur 20-an, dan menurun perlahan-lahan hingga umur 60 tahun atau lebih. Setelah itu tingkat penurunannya menjadi lebih cepat. Sehingga akan mempengaruhi kekuatan otot saat menekan atau menyemprot tekanan irigasi luka menggunakan flabot $^{13}$. Hasil penelitian terkait lainnya menyatakan bahwa tehnik pembersihan luka dengan irigasi lebih cepat menyembuhkan luka daripada tehnik usap. Maksimal tekanan irigasi yang diberikan adalah 15 psi dan dengan tekanan minimal 4 psi ${ }^{9}$. Penelitian lainnya menyatakan pengelolaan luka akut salah satunya dengan menggunakan irigasi luka dengan tekanan tertentu $^{10}$.

Irigasi luka dengan tekanan tertentu juga mampu untuk membersihkan luka trauma terbuka. Menurut hasil penelitian lainnya menyatakan bahwa irigasi luka mampu menghilangkan debris dan eksudat akibat kontaminasi bakteri pada perawatan luka fraktur terbuka ${ }^{1}$.

Hasil uji analisis rank spearman yang menunjukkan bahwa ada hubungan antara lama bekerja dengan tekanan irigasi luka. Hasil penelitian lainnya yang relevan menyatakan bahwa hubungan antara lama bekerja dengan ketrampilan perawat itu berbanding lurus. Semakin lama seorang perawat bekerja maka semakin baik juga 
ketrampilan yang dimiliki ${ }^{11}$.

Hasil penelitian relevan lainnya menyatakan bahwa semakin lama seorang perawat melakukan perawatan luka maka semakin banyak jumlah kasus yang ditangani dan hal ini tentu saja akan meningkatan pengalaman perawat tersebut. Hal itu juga berlaku sebaliknya, semakin sedikit jumlah pasien yang dilakukan perawatan luka maka semakin sedikit pula pengalaman perawat tersebut dalam melakukan perawatan luka. Pengalaman dalam menangani perawatan luka akan meningkatkan kemampuan, ketrampilan dan pemahaman tentang perawatan luka ${ }^{12}$.

Asumsi peneliti bahwa perawat yang lebih lama bekerja di bangsal bedah memiliki kemampuan dan pengalaman yang lebih baik dibandingkan perawat yang masa kerjanya lebih singkat di bangsal bedah. Akan tetapi dalam hal kekuatan otot saat melukan irigasi luka akan semakin menurun. Hal ini yang menurut peneliti berkontribusi besar terhadap tindakan irigasi luka saat perawat melakukan perawatan luka. Keterbatasan dalam penelitian ini belum melihat faktor-faktor lainnya seperti umur, lingkar lengan, dan jenis kelamin perawat.

\section{KESIMPULAN}

Semakin lama seorang perawat bekerja di bangsal bedah maka kemampuan dalam melakukan perawatan luka khususnya akan meningkat. Tekanan ideal irigasi luka akan tercapai pada perawat yang bekerja dalam kurun waktu yang singkat yang mana hal ini dapat dikaitkan dengan umur perawat tersebut. Adapun untuk penelitian berikutnya perlu melihat faktor lainnya yakni umur, jenis kelamin, dan lingkar lengan yang dihubungkan dengan tekanan irigasi luka.

\section{DAFTAR PUSTAKA}

1. Anglen, J,O.2010. Wound irrigation in muskuloskeletal injury. Journal the American Academy of Orthopaedic Surgeons, 9 (4) 219-226

2. American College Of Surgeons Commitee On Trauma. 2007. Trauma Toraks dalam ATLS Student Course Manual 8th edition. USA

3. Bhandari, M., Jeray, K. J., Petrisor, B. A., Ansdell, D. H., Schemitsch, E. H., Anglen, J., et al. 2015. A Trial of Wound Irrigation in the Initial Management of Open Fracture Wounds. N Engl J Med, 373:2629-2641.

4. Bryant R. A \& Nix D.P. 2007. Acute and Chronic Wounds Current Management Conceps (3rd ed). St. Louis Missoury: Mosby Elsevier.

5. Depkes RI. 2013. Riset kebutuhan dasar. Jakarta : Departemen Kesehatan RI

6. Diligence, M, M. 2009. Advanced Medical http://mediligence.com.

7. Faizin, A dan Winarsih. 2008. Hubungan tingkat pendidikan, lama kerja perawat dan kinerja perawatdi 
RSU Pandan Aran Kabupaten Boyolali. Berita Ilmu Keperawatan. Vol 1(3) 13742

8. Lloyd, J, M. 2012. Wound Cleansing. British Journal of Healthcare Assistants. 6(6): 267-71

9. Mak, et al. 2015. Pressurised irrigation versus swabbing method in cleansing wounds healed by secondary intention: A randomised controlled trial with costeffectiveness analysis. International Journal of Nursing Studies, Vol 5,88101

10. Nicks, et al. 2010. Acute wound management: revisiting the approach to assessment, irrigation, and closure consideration. Int J Emerg Med, 3(4) 399-407

11. Robbin, S.P, \& Judge. 2008. Perilaku organisasi, edisi ke-12. Jakarta : Salemba Empat

12. Sastrohadiwiryo, S. 2002. Manajemen tenaga kerja Indonesia. Jakarta: Bumi Aksara

13. Sharkey, B. J. 2003. Fitness And Health. Alih bahasa Kebugaran dan

Kesehatan. Jakarta: P.T. Raja Grafindo

Persada

14. Suyanto \& Amal,A.I. 2017. Modern wound irrigation device (MWID) reduce the number of bacteria in diabetic ulcer patients. INJEC, Vol 2 (1) 105-108 